\title{
Cadewors 72055
}

\section{UNIQUENESS OF WEIGHTED CODE REPRESENTATIONS, II* MAS}

\section{W. A. Beyer}

We define a 4-bit velghted BCD code with welghts $w_{1}$, w2, $w_{3}, w_{4}$ to be $a$ set $c$ or ten 4-bit numbers of the form $\left(b_{1} b_{2} b_{3} b_{4}\right)\left(b_{1}=0\right.$ or 1$)$ such that each integer $n(0 \leq n \leq 9)$ can be expressed as $n=\sum_{i=1}^{4} b_{i} w_{i}$ for some $\left(b_{2} b_{2} b_{3} b_{4}\right) \in C$. The $v_{1}$ are real.

Weeg ${ }^{l}$ has exhibited all such codes in case the $w_{1}$ are restricted to

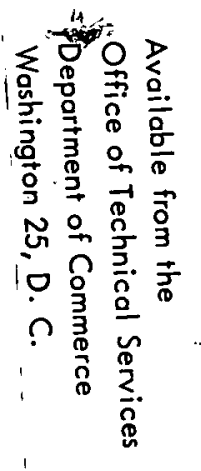

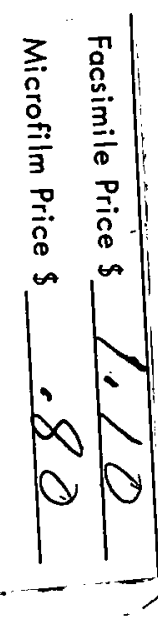
integers with $-9 \leq w_{1} \leq 9$. The purpose of this letter is to show that $v_{i}$ 's must be integers. This otill leaves the possibility that there are additional codes if the $w_{i}$ are integers outside the range from - 9 to 9. We note that none of Weeg's codes has a 9 for a w. No doubt the ract that no $w$ can be a 9 can be shown by methods other than Weeg's enumeration method.

Denote the set of all Integers by I and the reminder of the real numbers by F. Essentially, the proof uaes the triviality that if $x_{1}$ is in the subgroup I of the group of real numbers under addition and $x_{2}$ is in the complement of $I$, then $x_{1}+x_{2} \cdot$ is in the couplement of I. Incidentally, the formalization of this property of a subgroup can be used to define notion of a subgroup.

Consider a code C. Suppose one of the w's, say $w_{1}$, is in F. Since at lesst one member of $C$ mast have $b_{1}=1$, another $w$, say $w_{2}$, must be in $F$. Suppose $w_{3} \in I$ and $w_{4} \in I$. Then for any member of $C$ we must have $b_{1}=0, b_{2}=0$ or $b_{1}=1, b_{2}=1$. Thls allows only 8 members for $c$. Thus at lesst one of $w_{3}$ and $w_{4}$, say $w_{3}$, must be in F. Suppose $w_{4} \in I$. Then none of the six comblnations

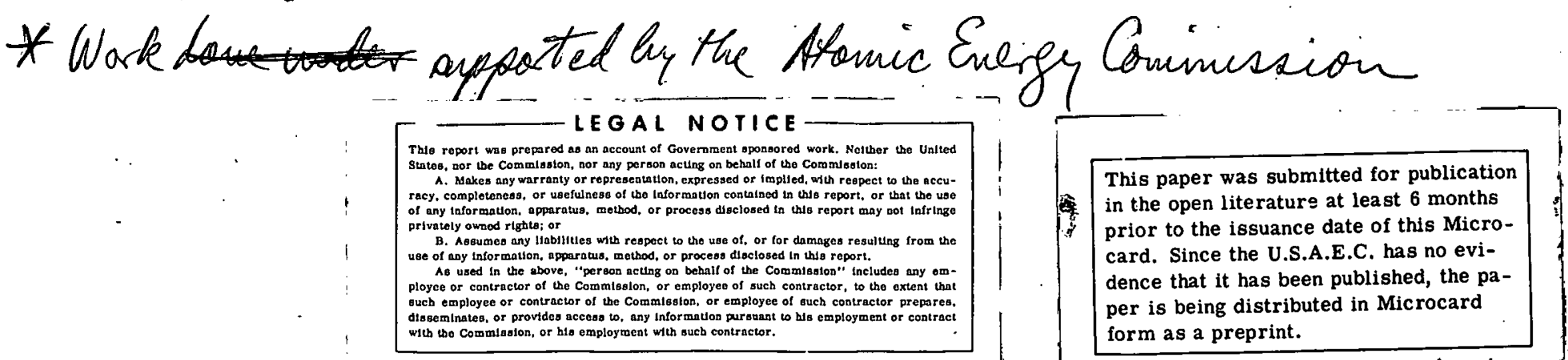




\section{DISCLAIMER}

This report was prepared as an account of work sponsored by an agency of the United States Government. Neither the United States Government nor any agency Thereof, nor any of their employees, makes any warranty, express or implied, or assumes any legal liability or responsibility for the accuracy, completeness, or usefulness of any information, apparatus, product, or process disclosed, or represents that its use would not infringe privately owned rights. Reference herein to any specific commercial product, process, or service by trade name, trademark, manufacturer, or otherwise does not necessarily constitute or imply its endorsement, recommendation, or favoring by the United States Government or any agency thereof. The views and opinions of authors expressed herein do not necessarily state or reflect those of the United States Government or any agency thereof. 


\section{DISCLAIMER}

Portions of this document may be illegible in electronic image products. Images are produced from the best available original document. 
(1000), (0100), (0010), (1001), (0101) and (0011) can be in C. If $w_{1}+w_{2} \in I$, then (1111)\&C and $(1110) \& C$. Thus $w_{1}+w_{2} \in F$. In this case $(2100) \& C$ and (1101)\&C. Thus $w_{4} \in \mathbb{F}$. So $w_{1} \in F, 1=1,2,3,4$. In this case none of the 4 combinations $(1000),(0100),(0010),(0001)$ are in C. Suppose $w_{1}+w_{2} \in I$. Then (1110)\&c and (1101)\&c. If $w_{3}+w_{4} \in I$, then $(1011) \& C$ and $(0111) \& c$. Thus

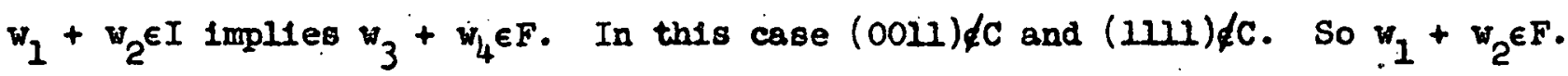
Then $(1100) \notin c$. If $w_{3}+w_{4} \in I$, then (III) \&C and $(0111) \notin C$. So $w_{3}+w_{4} \in F$. By permutation of the w's and repetition of the argument, we obtain that no sums of pairs of w's are in I. Thus none of (1100), (1010), (1001), (0110), (0101), and $(001)$ are in $C$. Thus $w_{1} \in I$ for $1=1,2,3,4$.

Note that $1 / 2,1 / 2,2,4,8$ are the w's for a 5-bit welghted BCD code.

W. A. Beyer Ios Alamos Sclentific Laboratory Untiversity of Californie Los Alamos, New Mexdco. 
$\therefore \therefore$

Recelved

$I_{G}$. P. Weeg, "Uniqueness of Welghted Code Representations", I.R.E. Transactions on Electronic Computers, vol. EC-8, pp. 487-489; Dec. 1960. 